\title{
Markers That are Used for Allergic Diseases Can the Be Used in Preeclampsia?
}

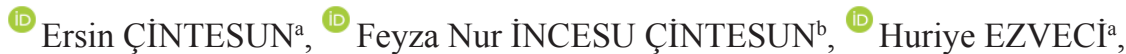 \\ ${ }^{[}$Fikret AKYÜREK ${ }^{\mathrm{c}},{ }^{\circledR}$ Denizhan BAYRAMOĞLU ${ }^{\mathrm{a}},{ }^{\circledR}$ Çetin ÇELIK ${ }^{\mathrm{a}}$ \\ ${ }^{a}$ Department of Obstetrics and Gynecology, Selçuk University Faculty of Medicine, Konya, TURKEY \\ ${ }^{\mathrm{b}}$ Clinic of Obstetrics and Gynecology, Konya Research and Training Hospital, Konya, TURKEY \\ 'Department of Biyochemistry, Selçuk University Faculty of Medicine, Konya, TURKEY
}

\begin{abstract}
Objective: We aimed to investigate the relationship between inflammatory markers used for allergic diseases and preeclampsia. Material and Methods: This retrospective case-control study included 162 patients comprising 81 patients in the control group and 81 patients in the preeclampsia group. The preeclampsia group was constituted by 40 patients with mild preeclampsia and 41 with severe preeclampsia. The basophil, eosinophil, eosinophil-basophil ratio (EBR), eosinophil-lymphocyte ratio (ELR), and basophil-lymphocyte ratio (BLR) values used in this study were taken into account before the initiation of any medical or surgical procedure. Results: EBR was significantly lower in the preeclampsia group than in the control group $(\mathrm{p}=0.033)$. Basophil $(\mathrm{p}=0.049)$ and $\mathrm{BLR}(\mathrm{p}=0.029)$ values were significantly higher in the preeclampsia group than in the control group. When the control group and preeclampsia subgroups were compared, ELR and EBR were significantly different between three groups $((\mathrm{p}=0.039$ and $\mathrm{p}=0.010$ respectively) but in binary comparison no difference was found As preeclampsia severity increased, EBR decreased, and ELR increased gradually. To predict preeclampsia, the receiver operating characteristic curve (ROC) analysis was used. The ROC analysis results of EBR was found as sensitivity $51.90 \%$, and specificity $69.1 \%$ (AUC:0.597, 95\% CI:0.51-0.68), and BLR was found as sensitivity 62.85\%, and specificity 59.78\% (AUC:0.600, 95\% CI:0.51-0.69). Conclusion: Allergy-related mechanisms may also play a role in the pathogenesis of preeclampsia. Allergic markers may be considered in the diagnosis and research of preeclampsia.
\end{abstract}

Keywords: Basophil; eosinophil; inflammation; lymphocyte; preeclampsia

Preeclampsia (PE) is characterized by new-onset hypertension after 20 weeks of gestation with proteinuria and/or end-organ dysfunction. The clinical manifestations differ depending on a wide range of microangiopathies in target organs, including the brain, liver, kidney, and placenta. ${ }^{1} \mathrm{PE}$ appears in nearly $4-6 \%$ of all pregnancies and is usually 1.5 to $2-$ times higher in first pregnancies. ${ }^{2}$ The placenta plays a crucial role in the pathogenesis. In this pathogenesis, a number of etiologies have been defined, including genetic, immunologic, and environmental..$^{3-6}$ An excessive reaction to encounters with paternal and/or fetal antigens forms the basis for those immunologic factors that cause abnormal placentation. ${ }^{7,8}$ Nulliparous women who change partners between pregnancies, who have long gestational intervals, who use barrier contraception, and who are pregnant through intracytoplasmic sperm injection, are less exposed to paternal antigens and have a higher risk of developing PE. ${ }^{9}$ The presence of these risk factors inspired this study.

Eosinophils, neutrophils, and basophils are white blood cells (WBC) of granulocytic lineage. The physiologic function of eosinophil and basophils remain a mystery although they are most likely involved in the immune response to infection, tumor surveillance, remodeling of tissue, and interactions of other immune cells. ${ }^{10}$ Eosinophils and basophils are mostly elevated in parasitic, helminth, allergic diseases, drug reactions, solid tumors, adrenal insufficiency, and vari-

\section{Correspondence: Ersin CINTESUN \\ Department of Obstetrics and Gynecology, Selçuk University Faculty of Medicine, Konya, TURKEY \\ E-mail: ersincintesun@gmail.com \\ Peer review under responsibility of Journal of Clinical Obstetrics \& Gynecology.


ous autoimmune diseases. ${ }^{11}$ In the literature, eosinophil-basophil ratio (EBR), eosinophil-lymphocyte ratio (ELR), and basophil-lymphocyte ratio (BLR) have been studied, mostly in allergic diseases. ${ }^{12-14}$ Some studies found that ELR was significantly lower in patients with nasal polyposis..$^{12,14}$ Some studies in the literature found significantly higher EBRs in patients with chronic rhinosinusitis, nasal polyps, and asthma. ${ }^{15}$ Although ELR, BLR, and EBR have not been examined in studies on patients with PE, variables such as eosinophils, basophils, and lymphocytes have been examined. Conflicting results have been found in the literature, and the number of eosinophils has been shown to decrease in patients with hypertension, and further decrease as disease severity increases. ${ }^{16}$ In these diseases, glucocorticoid release or use has been claimed to cause eosinophil apoptosis. ${ }^{17,18}$ In this study, we aimed to investigate these markers in PE.

\section{MATERIAL AND METHODS}

This is a retrospective, case-control study conducted at the department of obstetrics and gynecology in a university hospital. The local ethics committee approved the study $(2018 / 201,30 / 05 / 2018$, Selcuk University Local Ethics Committee). The study was performed in accordance with the principles of the World Medical Association Declaration of Helsinki Ethical Principles for Medical Research Involving Human Subjects.

The case and control group patients were selected among the patients admitted to the hospital between January $1^{\text {st }}, 2016$, and January $1^{\text {st }}, 2018$. A total of 162 patients were included in the study; 81 patients who experienced PE formed the study group, and 81 age-matched patients without $\mathrm{PE}$ constituted the control group. In the PE group, 40 patients had mild PE and 41 patients had severe PE. The control group was randomly selected from patients without PE and systemic disease, who were in their third trimester, and being followed up and treated in our hospital.

Inclusion criteria: Being aged 18-45 years, not having a known systemic disease, not having a known allergic disease, and singleton pregnancy. The diagnosis and severity criteria for PE were based on the criteria cited by the American College of Obstetrics and Gynecology in 2019. ${ }^{19}$ The exclusion criteria were having systemic diseases (e.g. diabetes, chronic hypertension), known active infection, and current medication use. Serum samples for complete blood count tests were collected on the early admission of patients to the hospital before the initiation of any medical treatment.

\section{STATISTICAL ANALYSIS}

The SPSS version 22 (SPSS Inc., Chicago, IL) software package was used for data analysis. The Kolmogorov-Smirnov test, histogram, and Q-Q plots were used to analyze the distribution of the data. Variables are given as mean ( \pm standard deviation) or median (minimum-maximum). Non-parametric tests (Mann-Whitney U test, Kruskal-Wallis test) and parametric tests [independent sample t-test, one-way analysis of variance (ANOVA)] were performed to compare data. The Mann-Whitney U and Tukey post hoc tests were used for multiple comparisons. Receiver operating characteristic (ROC) curve analysis was conducted to identify the optimal cut-off values of BLR and EBR. $p<0.05$ was considered statistically significant.

The required sample size was calculated using the $G^{*}$ Power software version 3.1.9.2 (*Heinrich Heine Universität; Düsseldorf; Germany) for the independent sample t-test, the $\alpha$-error probability at 0.05 , power (1- $\beta$ error probability) at $0.80 \%$, and effect size (d) at $0.45 .{ }^{20}$ The total number of 158 participants (79 in each group) were needed to achieve a statistically acceptable figure. To allow for dropouts, the sample size was increased to 162 patients.

\section{RESULTS}

Comparisons of demographic variables and laboratory data between the control and PE groups are shown in Table 1. No statistical differences were found between the two groups in terms of age, gravidity, parity, lymphocytes, eosinophils, and ELR $(p=0.201,0.735,0.214,0.841,0.410$, and 0.302, respectively). EBR was lower in the $\mathrm{PE}$ group than in the group ( $\mathrm{p}=0.033)$. Basophil $(\mathrm{p}=0.049)$ and BLR $(p=0.029)$ values were higher in the PE group than in the control group. 
TABLE 1: Comparison of demographic features, laboratory data between control and preeclampsia group.

\begin{tabular}{|lccc|}
\hline & Control $(\mathrm{n}=81)$ & Preeclampsia $(\mathrm{n}=81)$ & $\mathbf{p}$ \\
\hline Age $^{*}$ & $25(18-41)$ & $28(17-41)$ & 0.201 \\
Gravity $^{* *}$ & $2(1-5)$ & $2(1-13)$ & 0.735 \\
Parity $^{* *}$ & $1(0-3)$ & $1(0-6)$ & 0.214 \\
Lymphocyte $^{* *}$ & $1.980( \pm 0.72)$ & $2.01( \pm 0.62)$ & 0.841 \\
Eosinophil** $^{*}$ & $0.05(0.001-0.57)$ & $0.044(0.001-0.721)$ & 0.410 \\
Basophil $^{* *}$ & $0.04(0.01-1.56)$ & $0.048(0.1-0.381)$ & 0.049 \\
EBR $^{* *}$ & $1.280(0.004-57.0)$ & $0.930(0.81-16.50)$ & 0.033 \\
ELR $^{* *}$ & $0.020(0.00-0.32)$ & $0.024(0.001-0.55)$ & 0.302 \\
BLR $^{* *}$ & $0.020(0.0004-1.49)$ & $0.260(0.004-0.16)$ & 0.029 \\
\hline
\end{tabular}

EBR: Eosinophil basophil ratio; ELR: Eosinophil-lymphocyte ratio

BLR: Basophil-lymphocyte ratio. Values are given as median

(minimum-maximum) or mean ( \pm standard deviation).

* Independent sample t-test $\quad{ }^{* *}$ Mann-Whitney U test.

Comparisons of laboratory data among the three groups are shown in Table 2. There were significant differences between the three groups in terms of median age $(\mathrm{p}=0.021)$. There were no differences between the groups in terms of age, gravidity, parity, lymphocytes, eosinophils, basophils, and BLR $(p=0.239,0.445,0.373,0.869,0.128,0.070$, and
0.052, respectively). EBR $(\mathrm{p}=0.010)$ and ELR $(p=0.039)$ were significantly different among the groups. As PE severity increased, EBR decreased, and ELR increased gradually.

The ROC curve analysis was used to examine the performance of the EBR and ELR values in predicting PE. The ROC analysis results of EBR and BLR are shown in Table 3 and Figure 1. The ROC analysis results of EBR was found as sensitivity $51.90 \%$ and specificity $69.1 \%$ [area under the curve (AUC): $0.597,95 \%$ confidence interval (CI): 0.51$0.68]$, and BLR was found as sensitivity $62.85 \%$ and specificity $59.78 \%$ (AUC: $0.600,95 \%$ CI: $0.51-0.69$ ).

\section{DISCUSSION}

$\mathrm{PE}$ is a multi-systemic progressive disease caused by placental and maternal vascular dysfunction, and always resolves after delivery of the placenta. Even though most affected pregnancies deliver nearly at full term with no adverse maternal and fetal outcomes, these pregnancies are at increased risk for maternal or fetal mortality and morbidity. In addition,

\begin{tabular}{|c|c|c|c|c|c|c|c|}
\hline & $\begin{array}{l}\text { Control group } \\
\qquad(n=81)\end{array}$ & $\begin{array}{l}\text { Mild PE } \\
(\mathrm{n}=40)\end{array}$ & $\begin{array}{l}\text { Severe PE } \\
\qquad(n=41)\end{array}$ & $\begin{array}{c}\text { p value } \\
\text { (within } 3 \text { groups) }\end{array}$ & $\begin{array}{c}\text { p value } \\
\text { (Control vs. } \\
\text { Mild PE) }\end{array}$ & $\begin{array}{c}\text { p value } \\
\text { (Control vs. } \\
\text { Severe PE) }\end{array}$ & $\begin{array}{c}\text { p value } \\
\text { (Mild vs. } \\
\text { Severe PE) }\end{array}$ \\
\hline Age & $25(18-41)$ & $28(17-38)$ & $29(18-41)$ & $0.239^{++}$ & $>0.9^{* *}$ & $0.370^{* *}$ & $0.754^{* *}$ \\
\hline Gravidity & $2(1-5)$ & $2(1-5)$ & $2(1-13)$ & $0.445^{++}$ & $0.659^{++}$ & $0.328^{++}$ & $0.344^{++}$ \\
\hline Parity & $1(0-3)$ & $1(0-4)$ & $1(0-6)$ & $0.373^{++}$ & $0.151^{* *}$ & $0.552^{* *}$ & $0.561^{* *}$ \\
\hline Lymphocyte & $1.94(0.43-6.14)$ & $2.06(0.49-3.01)$ & $2.18(0.88-3.64)$ & $0.869^{+}$ & $>0.9^{+}$ & $0.897^{+}$ & $0.876^{+}$ \\
\hline Eosinophil & $0.05(0.001-0.57)$ & $0.05(0.001-0.721)$ & $0.038(0.001-0.66)$ & $0.128^{++}$ & $0.632^{* *}$ & $>0.9^{* *}$ & $0.596^{* *}$ \\
\hline Basophil & $0.04(0.01-1.56)$ & $0.04(0.02-0.137)$ & $0.05(0.01-0.38)$ & $0.070^{++}$ & $0.574^{* *}$ & $>0.9^{* *}$ & $0.655^{\star *}$ \\
\hline EBR & $1.28(0.006-57)$ & $1.34(0.02-15.6)$ & $0.60(0.004-16.5)$ & $0.010^{++}$ & $0.888^{* *}$ & $0.427^{\star *}$ & $0.681^{* *}$ \\
\hline ELR & $0.028(0.001-0.32)$ & $0.325(0.02-15.6)$ & $0.60(0.004-16.5)$ & $0.039^{++}$ & $0.168^{* *}$ & $0.886^{* *}$ & $0.120^{* *}$ \\
\hline BLR & $0.020(0.004-1.48)$ & $0.260(0.01-0.12)$ & $0.031(0.004-0.16)$ & $0.052^{++}$ & $0.616^{* *}$ & $>0.9^{* *}$ & $0.283^{\star \star}$ \\
\hline
\end{tabular}

PE: Preeclampsia; EBR: Eosinophil-basophil ratio; ELR: Eosinophil-lymphocyte ratio; BLR: Basophil-lymphocyte ratio.

Values are given as median (minimum-maximum) or mean ( \pm standard deviation).

Bold values represent statistically significant outcomes.

+ One-way ANOVA Tukey HSD; ${ }^{++}$Kruskal-Wallis test; ${ }^{* *}$ Mann-Whitney U test.

\begin{tabular}{|ccccccccc|}
\hline \multicolumn{7}{|c|}{ TABLE 3: EBR and BLR ROC analysis results. } \\
\hline AUC (95\% Cl) & p value & Cut-off value & Sensitivity & Specificity & PPV & NPV & Accuracy \\
EBR & $0.597(0.51-0.68)$ & 0.033 & 0.972 & $51.90 \%$ & $69.1 \%$ & $51.80 \%$ & $69.10 \%$ & $60.49 \%$ \\
BLR & $0.600(0.51-0.69)$ & 0.029 & 0.206 & $62.85 \%$ & $59.78 \%$ & $67.90 \%$ & $54.32 \%$ & $61.11 \%$ \\
\hline
\end{tabular}

EBR: Eosinophil-basophil ratio; BLR: Basophil-lymphocyte ratio. 


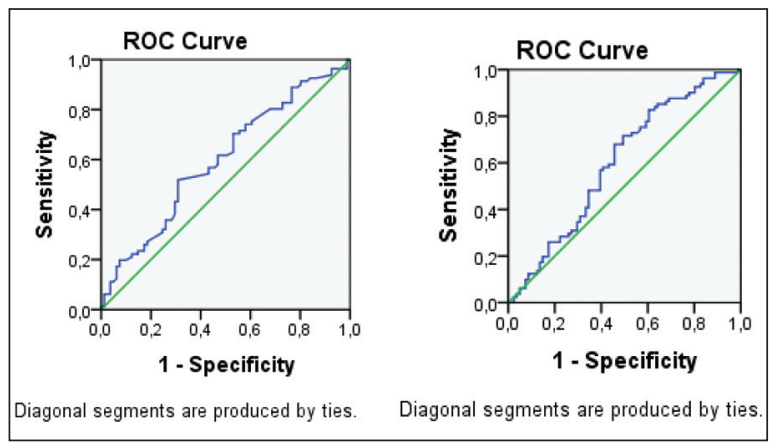

FIGURE 1: ROC curves of eosinophil-basophil ratio (EBR) basophil-lymphocyte ratio (BLR).

women with PE are at increased risk for future cardiovascular disease.

As epidemiological data and pathophysiologic mechanisms show that the main pathology is in the placenta in PE. The defect that may occur during the 2 -stage formation of the placenta causes PE. The fact that $\mathrm{PE}$ occurs in pregnancies after oocyte donation and happens after a sperm exposure for a short time suggest that excessive response to foreign antigens may also be a key or side pathway in the etiology of PE. When looking at the pathogenesis of allergic diseases, an inflammatory cascade is formed in allergic substance-susceptible people after allergen exposure, secreted by mast cells, immunoglobulin (Ig)-E, histamine, basophils, lymphocytes, various prostaglandins, and leukotrienes. Allergens adhere to $\operatorname{IgE}$ and then attach to receptors in mast cells and basophil cells, which is the mechanism that initiates pathogenesis. After allergic reactions begin, mast cells amplify such reactions by releasing vasoactive agents, cytokines, including granulocyte-macrophage colony-stimulating factor (GM-CSF), tumor necrosis factor-alpha (TNF- $\alpha$ ), transforming growth factorbeta (TGF- $\beta$ ), interleukin (IL)-1 to IL-6, and IL-13. Tissue eosinophilia is characteristic of allergic diseases. Eosinophils secrete a plethora of cytokines including IL-3, IL-4, IL-5, IL-10, and GM-CSF. ${ }^{21}$ Eosinophils release oxygen radicals and proteins such as eosinophil cationic protein, and eosinophil peroxidases. These have been shown to be associated with epithelial injury and desquamation, subepithelial fibrosis, and hyper-responsiveness. ${ }^{22}$ Basophils contribute to the allergic reaction by secreting histamine, like mast cells. ${ }^{23}$ Allergy and PE can use common cy- tokines and prostaglandins in the inflammation stage. We aimed to investigate whether there was a relationship between PE and allergy. We also investigated whether there was a relationship between allergy markers and PE severity. We were only able to use basophil and eosinophil values in our study because used complete blood count results.

Basophils that represent about $0.5 \%$ to $1 \%$ of leukocytes have a crucial role in the immune system. Basophils can release IL-4, whether or not in a IgEdependent manner, in response to a variety of stimuli. IL-4 promotes the differentiation of CD4+ T cells into T helper 2 (Th2) cells. In addition, IL-4 increases the level of eosinophils by increasing the release of CCL11 (known as eosinophil chemotactic protein). ${ }^{24,25}$ Basophils and eosinophils play important roles in various host defense mechanisms, but they also act as harmful effectors in allergic disorders. Basophils and eosinophils have also been investigated in other diseases. ${ }^{26,27}$ Studies on patients with PE with basophil and eosinophil counts are also available. Basophil and eosinophil counts are increased in allergic diseases..$^{15}$ There are different results in studies that investigated the patients with PE. ${ }^{28}$ In some studies, the eosinophil counts were found to be low in patients with PE. ${ }^{28}$ In another study, both eosinophils and basophils were found to be high in the PE group. ${ }^{23}$ In our study, the eosinophil counts were similar in both groups, whereas basophil counts in patients with PE were significantly higher.

Eosinophils and basophils were found to vary in patients with PE, whereas lymphocyte counts were not variable. ${ }^{28-30}$ Evaluation of these markers may not be appropriate due to hemodilution in normal pregnancy and hemoconcentration in PE. The ratio of these markers to each other is used to diagnose diseases. ELR, BLR, and EBR have mostly been investigated in allergy and other diseases. ${ }^{12,13,31}$ In studies by Kara et al., and Yenigun et al., ELR and BLR were found to be higher in allergic disease groups. ${ }^{12,13} \mathrm{In}$ the literature, there are no studies of ELR, BLR, and EBR in PE groups. In our study, EBR was significantly lower and BLR was significantly higher in the PE group. When comparing the control group with the mild-severe PE group, EBR and ELR were found to be significantly different between the groups. As 
PE severity increased, EBR decreased, and ELR increased gradually. When the data were analyzed, it was observed that basophil counts were higher than eosinophil. The mean lymphocyte counts appeared to be similar in both groups. We can say that the increase between the groups in EBR and ELR was due to the increase in basophilia in patients with PE compared with eosinophils. There are conflicting results related to eosinophil and basophil changes in patients with PE. ${ }^{16,28,32}$ It was claimed that the decrease in the number of eosinophils was associated with apoptosis caused by cortisol released into the circulation. ${ }^{17,18}$ However, there are insufficient data to explain the basophil change.

The limitations of this study are its retrospective design, the collection of data from a single center and the relatively small population, lack of allergy markers such as mast cells, IgE levels, and clear allergy history of the patients with PE. The strength of the study is that this subject has never been investigated before and PE severity subgroups were also examined.

\section{CONCLUSION}

As shown in our study, allergy-related mechanisms may also play a role in the pathogenesis of PE. If this relationship is shown more clearly, the treatment strategies used in allergic diseases may be considered in the prevention and treatment of PE in the future.

\section{Source of Finance}

During this study, no financial or spiritual support was received neither from any pharmaceutical company that has a direct connection with the research subject, nor from a company that provides or produces medical instruments and materials which may negatively affect the evaluation process of this study.

\section{Conflict of Interest}

No conflicts of interest between the authors and / or family members of the scientific and medical committee members or members of the potential conflicts of interest, counseling, expertise, working conditions, share holding and similar situations in any firm.

\section{Authorship Contributions}

Idea/Concept: Ersin Çintesun, Feyza Nur İncesu Çintesun, Huriye Ezveci; Design: Ersin Çintesun, Feyza Nur Incesu Çintesun; Control/Supervision: Fikret Akyürek, Çetin Çelik; Data Collection and/or Processing: Huriye Ezveci, Denizhan Bayramoğlu, Çetin Çelik; Analysis and/or Interpretation: Ersin Çintesun, Feyza Nur İncesu Çintesun, Huriye Ezveci, Denizhan Bayramoğlu, Fikret Akyürek, Çetin Çelik; Literature Review: Ersin Çintesun, Huriye Ezveci, Fikret Akyürek, Denizhan Bayramoğlu, Çetin Çelik; Writing the Article: Ersin Çintesun; Critical Review: Ersin Çintesun, Denizhan Bayramoğlu, Çetin Çelik; References and Fundings: Feyza Nur İncesu Çintesun, Huriye Ezveci; Materials: Ersin Çintesun, Çetin Çelik.

\section{REFERENCES}

1. Lain KY, Roberts JM. Contemporary concepts of the pathogenesis and management of preeclampsia. JAMA. 2002;26;287(24):31836. [Crossref] [PubMed]

2. Ananth CV, Keyes KM, Wapner RJ. Preeclampsia rates in the United States, 19802010: age-period-cohort analysis. BMJ. 2013;7;347:f6564. [Crossref] [PubMed] [PMC]

3. Gleicher N. Why much of the pathophysiology of preeclampsia-eclampsia must be of an autoimmune nature. Am J Obstet Gynecol. 2007;196(1):5.e1-7. [Crossref] [PubMed]

4. Esplin MS, Fausett MB, Fraser A, Kerber R, Mineau G, Carrillo J, et al. Paternal and maternal components of the predisposition to preeclampsia. N Engl J Med. 200;22;344(12): 867-72. [Crossref] [PubMed]

5. Madazlı R, Bulut B, Aydın B, Demirayak G, Kucur M. [First-trimester maternal serum metastin levels, chitotriosidase activity and uterine artery Doppler findings in preeclampsia]. Turkiye Klinikleri J Gynecol Obst. 2012;22(4):211-5.

6. AbdAlla S, Lother $\mathrm{H}$, el Massiery A, Quitterer $U$. Increased AT(1) receptor heterodimers in preeclampsia mediate enhanced angiotensin II responsiveness. Nat Med. 2001;7(9):10039. [Crossref] [PubMed]

7. Einarsson JI, Sangi-Haghpeykar H, Gardner MO. Sperm exposure and development of preeclampsia. Am J Obstet Gynecol. 2003;188(5):1241-3. [Crossref] [PubMed]

8. Klonoff-Cohen HS, Savitz DA, Cefalo RC, McCann MF. An epidemiologic study of contraception and preeclampsia. JAMA. 1989;8;262(22):3143-7. [Crossref] [PubMed]

9. Masoudian P, Nasr A, de Nanassy J, FungKee-Fung K, Bainbridge SA, El Demellawy D, et al. Oocyte donation pregnancies and the risk of preeclampsia or gestational hypertension: a systematic review and metaanalysis. Am J Obstet Gynecol. 2016;214(3):328-39. [Crossref] [PubMed]

10. Roufosse F, Weller PF. Practical approach to the patient with hypereosinophilia. J Allergy Clin Immunol. 2010;126(1):39-44. [Crossref] [PubMed] [PMC]

11. Ackerman SJ, Bochner BS. Mechanisms of eosinophilia in the pathogenesis of hypereosinophilic disorders. Immunol Allergy Clin North Am. 2007;27(3):357-75. [Crossref] [PubMed] [PMC]

12. Kara A, Guven M, Yilmaz MS, Demir D, Elden $\mathrm{H}$. Are neutrophil, platelet and eosinophil-tolymphocyte ratio and red blood cell distribution width can be used for nasal polyposis? Eur Arch Otorhinolaryngol. 2018;275(2):40913. [Crossref] [PubMed] 
13. Yenigün A. Assessment of patients with nasal polyposis by the neutrophil-to-lymphocyte ratio and eosinophil-to-lymphocyte ratio. Kulak Burun Bogaz Ihtis Derg. 2015;25(4):193-9. [Crossref] [PubMed]

14. Zhang XY, Simpson JL, Powell H, Yang IA, Upham JW, Reynolds PN, et al. Full blood count parameters for the detection of asthma inflammatory phenotypes. Clin Exp Allergy. 2014;44(9):1137-45. [Crossref] [PubMed]

15. Brescia G, Barion U, Zanotti C, Cinetto F, Giacomelli L, Martini A, et al. Blood eosinophilto-basophil ratio in patients with sinonasal polyps: does it have a clinical role? Ann Allergy Asthma Immunol. 2017;119(3):223-6. [Crossref] [PubMed]

16. Mtali YS, Lyimo MA, Luzzatto L, Massawe SN. Hypertensive disorders of pregnancy are associated with an inflammatory state: evidence from hematological findings and cytokine levels. BMC Pregnancy Childbirth. 2019; 19(1):237. [Crossref] [PubMed] [PMC]

17. Xu Z, Zhao F, Lin F, Xiang H, Wang N, Ye D, et al. Preeclampsia is associated with a deficiency of lipoxin A4, an endogenous anti-inflammatory mediator. Fertil Steril. 2014;102(1): 282-90.e4. [Crossref] [PubMed]

18. Ilmarinen $P$, Kankaanranta $H$. Eosinophil apoptosis as a therapeutic target in allergic asthma. Basic Clin Pharmacol Toxicol. 2014;114(1):109-17. [Crossref] [PubMed]

19. ACOG practice bulletin no. 202: gestational hypertension and preeclampsia. Obstet Gynecol. 2019;133(1):e1-e25. [PubMed]
20. Faul F, Erdfelder E, Lang AG, Buchner A. $G^{*}$ power 3: a flexible statistical power analysis program for the social, behavioral, and biomedical sciences. Behav Res Methods. 2007;39(2):175-91. [Crossref] [PubMed]

21. Eifan AO, Durham SR. Pathogenesis of rhinitis. Clin Exp Allergy. 2016;46(9):1139-51. [Crossref] [PubMed]

22. Christodoulopoulos $P$, Cameron L, Durham $S$, Hamid Q. Molecular pathology of allergic disease. II: upper airway disease. J Allergy Clin Immunol. 2000;105(2 Pt 1):211-23. [Crossref] [PubMed]

23. Naclerio RM, Proud D, Togias AG, Adkinson Jr NF, Meyers DA, Kagey-Sobotka A, et al. Inflammatory mediators in late antigen-induced rhinitis. N Engl J Med. 1985;11;313(2):65-70. [Crossref] [PubMed]

24. Yamanishi $\mathrm{Y}$, Karasuyama H. Basophil?derived IL?4 plays versatile roles in immunity. Semin Immunopathol. 2016;38(5):615-22. [Crossref] [PubMed]

25. Otsuka A, Nonomura Y, Kabashima K. Roles of basophils and mast cells in cutaneous inflammation. Semin Immunopathol. 2016; 38(5):563-70. [Crossref] [PubMed]

26. Yalcin AD, Kargi A, Gumuslu S. Blood eosinophil and platelet levels, proteomics patterns of trail and CXCL8 correlated with survival in bevacizumab treated metastatic colon cancers. Clin Lab. 2014;60(2):339-40. [Crossref] [PubMed]

27. Wei Y, Zhang X, Wang G, Zhou Y, Luo M,
Wang S, et al. The impacts of pretreatment circulating eosinophils and basophils on prognosis of stage I-III colorectal cancer. Asia Pac J Clin Oncol. 2018;14(5):e243-e51. [Crossref] [PubMed]

28. Lurie S, Frenkel E, Tuvbin Y. Comparison of the differential distribution of leukocytes in preeclampsia versus uncomplicated pregnancy. Gynecol Obstet Invest. 1998;45(4): 229-31. [Crossref] [PubMed]

29. Canzoneri BJ, Lewis DF, Groome L, Wang Y. Increased neutrophil numbers account for leukocytosis in women with preeclampsia. Am J Perinatol. 2009;26(10):729-32. [Crossref] [PubMed] [PMC]

30. Yavuzcan A, Caðlar M, Ustün Y, Dilbaz S, Ozdemir I, Yildiz E, et al. Mean platelet volume, neutrophil-lymphocyte ratio and plateletlymphocyte ratio in severe preeclampsia. Ginekol Pol. 2014;85(3):197-203. [Crossref] [PubMed]

31. Gambichler T, Brown V, Steuke AK, Schmitz L, Stockfleth E, Susok L, et al. Baseline laboratory parameters predicting clinical outcome in melanoma patients treated with ipilimumab: a single-centre analysis. J Eur Acad Dermatol Venereol. 2018;32(6):972-7. [Crossref] [PubMed]

32. Örgül G, Aydýn Haklý D, Özten G, Fadiloðlu E, Tanacan A, Beksaç MS, et al. First trimester complete blood cell indices in early and late onset preeclampsia. Turk J Obstet Gynecol. 2019;16(2):112-7. [Crossref] [PubMed] [PMC] 